\title{
OUR PEOPLE, OUR HEALTH, OUR FUTURE: MURDI PAAKI REGIONAL COUNCIL HEALTH SUMMIT
}

Margaret Lesjak

NSW Public Health Officer Training Program

Julianne Quaine and Hugh Burke

Far West Area Health Service

on behalf of the Murdi Paaki Regional Council Health

Summit Steering Committee

'I feel like all I do lately is travel to and from funerals of my friends and family. The communities of this Region deserve a better outlook than that. ATSIC identified the need for an immediate overview of this region's needs and access to health services. The findings will be used at a peak forum where these issues can be addressed practically.'

This quote from Steve Gordon, the Aboriginal and Torres Strait Islander Commission (ATSIC) Zone Commissioner for Western NSW, outlines the objectives of the Murdi Paaki Regional Council (MPRC) Health Summit entitled 'Our People, Our Health, Our Future'. The summit will be held over 14-16 June 2000 at Dareton, a small community on the Murray River near Mildura.

The MPRC Health Summit has been planned and coordinated by a steering committee which consists of representatives of the regional council, Aboriginal community controlled health organisations in the region, and the Far West and Macquarie Area Health Services. Funding has been provided by ATSIC, Maari Ma Health Aboriginal Corporation, Far West Area Health Service, and the NSW Department of Health.

This article describes the development of the MPRC Health Summit, the eight health issues the summit plans to consider, and the study tours of the Murdi Paaki region by national experts - the findings of which will inform the discussion.

\section{THE MURDI PAAKI REGIONAL COUNCIL PLAN}

One responsibility of the ATSIC Regional Councils is to formulate regional plans to improve the social, cultural and economic status of Aboriginal people. The Murdi Paaki ATSIC Region is one of the six ATSIC regions in NSW, and covers most of western NSW. The region has similar, but slightly larger, geographical boundaries to those of the Far West Area Health Service. The Murdi Paaki Regional Council is responsible for representing the interests of the 5,902 indigenous people residing in the Murdi Paaki Region.
In 1995, the Murdi Paaki Regional Council Plan expressed the following goal for indigenous health: 'To improve the health standards of Aboriginal and Torres Strait Islander people in the Murdi Paaki Region.'

Strategies for achieving this goal were developed and they include:

- implementation of the recommendations of the National Aboriginal Health Strategy;

- development and enhancement of the Aboriginal community-controlled health and rehabilitation services;

- improvement of access to NSW Health programs, and health professional services, to all residents in the Murdi Paaki Region. ${ }^{1}$

\section{REPRESENTATION THE MURDI PAAKI REGION HEALTH SUMMIT}

The MPRC Health Summit will bring together a wide range of individuals and groups to address major health issues as an urgent response to the high rates of illness and premature death among Aboriginal people in far western and north western NSW. These include:

- local Aboriginal community-controlled health organisations

- mainstream health service staff

- representatives from relevant state and community government agencies

- identified health issue experts

- mainstream and indigenous health workers

- other relevant agencies in the Murdi Paaki Region.

\section{THE DEVELOPMENT OF HEALTH ISSUES FOR DISCUSSION}

Eight health issues were identified by the MPRC Health Summit Steering Committee to be the highest priority for the Murdi Paaki people. National experts in each of these health issues were engaged to provide consultation and input to the Health Summit. The priority health issues, and the relevant experts, are listed in Table 4.

The five-day study tours of the Murdi Paaki Region were conducted to examine each of the eight priority health issues and were led by the relevant expert(s). This approach oriented the experts to far western NSW and gave representatives to the summit the opportunity to consult with community members and relevant 


\begin{tabular}{|ll|}
\hline TABLE 4 \\
\hline $\begin{array}{l}\text { MURDI PAAKI REGIONAL HEALTH SUMMIT: HEALTH ISSUES FOR DISCUSSION AND } \\
\text { IDENTIFIED EXPERT }\end{array}$ \\
\hline Health issue & Expert \\
\hline Child Health & Professor Michael Gracey \\
Maternal Health & Ms Maggie Haertsch \\
Alcohol issues and violence & Dr Peter D'Abbs \\
Youth Suicide & Professor Ernest Hunter \\
Lifestyle-related illnesses & Professor Kerin O'Dea \\
such as diabetes and heart disease & Dr Michael Douglas \\
Environmental Heath & Professor Charles Kerr, Ms Judith Burns and Mr Cliff Chenery \\
Employment & Dr Sandra Meihubers \\
Oral Health & \\
& \\
\hline
\end{tabular}

stakeholders about their expectations of health services, and their preferred outcomes and strategies for achieving these outcomes. Each expert is required to provide consultation and input to the summit.

Tours visited a range of communities in the region including Walgett, Brewarrina, Bourke, Wilcannia, Menindee, Dareton and Broken Hill. Discussions were held with mainstream and Aboriginal controlled community health organisation's staff, representatives from non-health agencies and organisations, and the community. Non-health agencies included departments of Police, Education, Community Services, Community Development Employment Projects (CDEP), and local councils.

The three-day Summit is devised as a planning forum to generate recommendations and practical strategies to improve the health of the indigenous people in the Murdi
Paaki Region. The papers will be presented and discussed at workshops facilitated by the appropriate expert. The output will be a plan including mutually agreed, practical strategies which agencies and organisations can take with them for implementation, if appropriate.

\section{REFERENCES}

1. Murdi Paaki Regional Council. Regional Plan for the Murdi Paaki Region. Bourke, NSW: Murdi Paaki Regional Council, 1995. it:

For further information on the Murdi Paaki Regional Health Summit please contact the conference organiser MADEC on (03) 50237233. 